\title{
Impact of Roadways in Tamilnadu
}

\author{
${ }^{1}$ Ms. K. Neela Pushpam, ${ }^{2}$ Dr. S. Palanichamy, \\ ${ }^{I}$ Asst. prof. of History, S.F.R. College for Women, Sivakasi, \\ ${ }^{2}$ Associate \& Head, Department of HistoryVHNSN College, Virudhunagar.
}

\begin{abstract}
The Indian economy is set to grow at a rapid pace recovering swiftly from the downturn. While services is expected to retain its position as the top contributor to GDP, manufacturing and agriculture are also experiencing brisk growth. Physical infrastructure augmentation would be essential to maintain and enhance this pace of growth moving forward. There is a strong interest in the Indian infrastructure story, with transportation being the key lever in the same. The investment in roads, rail, ports and aviation, often in the form of public-private partnerships, has provided a fillip to infrastructure creation in the country. But as far as Tamil Nadu is concerned, roadways is a well developed basic infrastructure. This sector makes large scale production possible by ensuring an adequate flow of raw materials and manpower and enlarging the potential market for such production. It extends the frontiers of employment for labour, capital and enterprise and helps in bringing about economic and social integration. A World Bank report says : "The major lag in Indian transport development is on roads, where the effects of the revolution in the means of transport, which have drastically changed the transport picture in other countries, have been so muted as to seriously impede the progress of the country towards economic development
\end{abstract}

key words :Economic Development, Bus Services, Road and Agriculture

\section{Introduction:}

The Indian economy is set to grow at a rapid pace recovering swiftly from the downturn. While a service is expected to retain its position as the top contributor to GDP, manufacturing and agriculture are also experiencing brisk growth. Physical infrastructure augmentation would be essential to maintain and enhance this pace of growth moving forward. There is a strong interest in the Indian infrastructure story, with transportation being the key lever in the same. The investment in roads, rail, ports and aviation, often in the form of public-private partnerships, has provided a fillip to infrastructure creation in the country.Tamil Nadu is the $3^{\text {rd }}$ biggest state in urbanization by virtue of development achieved in the fields of industry and many other sectors.

\section{Economic Development}

According to a study by Asian Development Bank (ADB), there exist a strong correlation between investment in road infrastructure and prosperity in any particular region. The study finds that there is a two-fold effect of such investments - i) The overall economic growth is positively affected by the stock of road assets, and ii) Income inequality declines as the quantity and quality of road infrastructure improves. The foremost objective of economic development programme is to maximise production - agricultural and industrial.

Road sector has a special role in the economic development of the country. It generates the basic infrastructure necessary for the building up of an economy in a smoother manner. Benefits from the investment in public goods are not easy to trace. A majority of benefits from such investment are indirect. Monetary value of benefit accrued due to the development of road and improved transportation was Rs. 131.81 lakhs in Tamil Nadu.

\section{Socio-Economic Impact}

The socio-economic impact that road sector offers is chiefly in terms of reduced travel time and costs and accessibility to key nerve centres for the nodal population. This in turn, spawns value added services like transport services, improves access to primary services and provides greater avenues for income and employment.

\section{Reduced Travel Time and Costs}

Greatly reduced travel time and costs across national highways helps easier access to major health centres and markets in bigger towns and cities. Similarly, through improved State and rural highways, local villages and communities get primary access to socio-economic services and agricultural markets.

Access to Public Services 


\section{(i) Fire Service Facility}

Yet another benefit found is the utilisation of fire service facilities. Usually the fire stations are located in one or two places in the district. Being a developing country and most of the population living near the fields in rural areas, houses are not fire proof. The agricultural produce is stored in the houses. The straw and other feed for their bullocks are heaped almost near the houses and are susceptible to fire accidents. The lack of road facility and absence of short cut routes delay the fire service from reaching a fire in a village in time to prevent total damage. This would be remedied to a great extent by implementing the link road schemes. The above fact is confirmed in the Table furnished below.

Fire service (at Salem)

\begin{tabular}{|l|c|c|c|c|}
\hline $\begin{array}{c}\text { Name of the } \\
\text { Village in Salem } \\
\text { District }\end{array}$ & \multicolumn{2}{|c|}{ Distance from the village } & \multicolumn{2}{c|}{ Time taken to reach the village } \\
\cline { 2 - 5 } & $\begin{array}{c}\text { Before } \\
\text { implementation }\end{array}$ & $\begin{array}{c}\text { After } \\
\text { implementation }\end{array}$ & $\begin{array}{c}\text { Before } \\
\text { implementation }\end{array}$ & $\begin{array}{c}\text { After } \\
\text { implementation }\end{array}$ \\
\hline K.Morur & $46.2 \mathrm{~km}$ & $46.2 \mathrm{~km}$ & $1 \mathrm{hr} 9 \mathrm{mts}$ & $46 \mathrm{mts}$ \\
\hline Chinnavadagampatti & $36 \mathrm{~km}$ & $36 \mathrm{~km}$ & $54 \mathrm{mts}$ & $36 \mathrm{mts}$ \\
\hline Lokkur & $40.2 \mathrm{~km}$ & $40.2 \mathrm{~km}$ & $1 \mathrm{hr}$ & $40 \mathrm{mts}$ \\
\hline Kanaraipudur & $46 \mathrm{~km}$ & $46 \mathrm{~km}$ & $1 \mathrm{hr} 9 \mathrm{mts}$ & $46 \mathrm{mts}$ \\
\hline
\end{tabular}

\section{(ii) Police Station Facility}

The road project also ensure a better law and order situation in the State. Due to non availiability of roads, police help was not fully available to the villagers. Crime would be reduced to some extent and timely police assistance reach the villagers when needed after the construction of roads. The table shows that the villagers have been able to report to the police an increasing number of crimes after the construction of roads. Since there is road facility, it is convenient for the people to go at once to the police station to report the crime, and it is also possible for police personnel to reach the village to take further action on the crimes reported.

Police service (at Salem)

\begin{tabular}{|l|c|c|c|c|}
\hline \multirow{2}{*}{$\begin{array}{c}\text { Name of the Village } \\
\text { in Salem District }\end{array}$} & \multicolumn{2}{|c|}{ Distance from the village } & \multicolumn{2}{c|}{ No. of crimes reported } \\
\cline { 2 - 5 } & $\begin{array}{c}\text { Before } \\
\text { implementation }\end{array}$ & $\begin{array}{c}\text { After } \\
\text { implementation }\end{array}$ & $\begin{array}{c}\text { Before } \\
\text { implementation }\end{array}$ & $\begin{array}{c}\text { After } \\
\text { implementation }\end{array}$ \\
\hline K.Morur & $22.1 \mathrm{~km}$ & $21.1 \mathrm{~km}$ & 6 & 8 \\
\hline Chinnavadagampatti & $11.9 \mathrm{~km}$ & $11.9 \mathrm{~km}$ & 2 & 3 \\
\hline Lokkur & $16.1 \mathrm{~km}$ & $16.1 \mathrm{~km}$ & 10 & 12 \\
\hline Kanaraipudur & $21.9 \mathrm{~km}$ & $21.9 \mathrm{~km}$ & 2 & 3 \\
\hline
\end{tabular}

\section{(iii) Mail Service Facility}

Yet another impact due to the construction of roads is quick mail service. After implementation of the road project, the communication facilities like postal service have increased and ensure proper and timely communication of information to the rural people.

\section{Increase in land value}

The development of a highway would enhance the value of agricultural, residential and commercial lands in or around the area, increase agricultural and industrial production, increase trade and commerce and in short the overall economic development of the area. The value of the lands on either side of a newly constructed rural road to an average depth of 60 metres usually increases. 15 acres of land on either side of the highway per each kilometre of the road appears to be benefitted.

The table furnished below provides the details of the land value before and after the construction of rural roads in Salem district.

\begin{tabular}{|l|c|c|c|c|c|c|}
\hline $\begin{array}{c}\text { Name of the Village in } \\
\text { Salem District }\end{array}$ & \multicolumn{2}{|c|}{ Value of land } & \multicolumn{2}{c|}{$\begin{array}{c}\text { Crop cultivated in } \\
\text { Tonnes }\end{array}$} & \multicolumn{2}{c|}{$\begin{array}{c}\text { Revenues from land } \\
\text { registration }\end{array}$} \\
\cline { 2 - 7 } & Before & After & Before & After & Before & After \\
\hline Chinnavadagampatti & 10,000 & 12,000 & 1,327 & 1,426 & 715 & 898 \\
\hline
\end{tabular}




\section{OTHER IMPACTS}

The construction of the road has made it possible to bring under plough the lands which were hitherto marginal or infra-marginal. After the new road was opened, two bus companies began operations. Regional milling and pottery industries were established, the fishing industry expanded, and many retail shops were opened. The outputs of items like basket, pottery, cloth and fish have also increased ranging from 11 per cent to 108 per cent. The increase in the industrial output after the construction of the road is highlighted in the table furnished below.

\begin{tabular}{|c|c|c|c|}
\hline \multirow[t]{2}{*}{ Industry } & \multicolumn{2}{|c|}{ Production } & \multirow{2}{*}{$\begin{array}{c}\text { Increase }(+) \text { or } \\
\text { Decrease } \\
(-) \text { (per cent) }\end{array}$} \\
\hline & $\begin{array}{l}\text { Before the road } \\
\text { was built }\end{array}$ & $\begin{array}{l}\text { After the road } \\
\text { was built }\end{array}$ & \\
\hline Mat weaving (Nos in '000) & 1104 & 1281 & +16.3 \\
\hline Basket making (") & 142 & 183 & +28.9 \\
\hline Fire wood (Tons) & 8235 & 10004 & +180.9 \\
\hline Fishery (Tons) & 623 & 857 & +37.6 \\
\hline Jagree (Tons) & 612 & 810 & +32.4 \\
\hline Milling (Tons) & 12 & 25 & +108.3 \\
\hline Pottery (Nos. in '000) & 7520 & 16920 & +125.0 \\
\hline Fibre (Tons) & 46 & 51 & +10.9 \\
\hline Rope making ( 15 ropes in ' 000$)$ & 38 & 42 & +10.5 \\
\hline
\end{tabular}

\section{ROAD AND AGRICULTURE}

A study on Ramnad-Mandapam road also showed that after the construction of new road, there is an increase in the area of cultivation. The table furnished below shows the area under cultivation before and after construction of road.

\begin{tabular}{|c|c|c|c|c|r|}
\hline \multirow{2}{*}{$\begin{array}{c}\text { Distance from the } \\
\text { highway in miles }\end{array}$} & $\begin{array}{c}\text { No. of } \\
\text { villages }\end{array}$ & \multicolumn{2}{|c|}{ Area cultivated (acres) } & $\begin{array}{c}\text { Per cent } \\
\text { increase }\end{array}$ & $\begin{array}{c}\text { Cultivated area per } \\
\text { mile in 1958-59 }\end{array}$ \\
\cline { 3 - 4 } & & $\mathbf{1 9 5 4 - 5 5 *}^{*}$ & $\mathbf{1 9 6 8 - 6 9 * *}$ & & \\
\hline $0-1$ & 5 & 2,500 & 3,000 & 2.0 & 2,500 \\
\hline $1-2$ & 5 & 3,600 & 3,700 & 2.8 & 2,050 \\
\hline $2-3$ & 5 & 5,800 & 6,100 & 5.2 & 950 \\
\hline $3-4$ & 5 & 3,700 & 3,800 & 2.7 & 380 \\
\hline $4-5$ & 5 & 1,200 & 1,900 & 58.3 & \\
\hline
\end{tabular}

* Before the construction of the road.

** After the construction of the road.

Table shows that the growth rate of cultivation is low around the highway upto 4 miles and the highest increase is in villages situated between 4-5 miles from the road and is claimed to be due to the fact that the construction of the road has made it profitable to bring under plough lands which were hitherto marginal and infra-marginal. Because of the construction of the road, the area cultivated increased by 12 per cent and the agricultural production increased by 16 per cent. The following table shows the rate of increase in respect of the various agricultural commodities after the construction of the road.

\begin{tabular}{|c|c|c|c|}
\hline \multirow[t]{2}{*}{ Commodity } & \multicolumn{2}{|c|}{ Production in tons } & \multirow{2}{*}{$\begin{array}{l}\text { Increase }(+) \text { or } \\
\text { Decrease (-) } \\
\text { (per cent) }\end{array}$} \\
\hline & $\begin{array}{c}\text { Before the road was } \\
\text { built }\end{array}$ & $\begin{array}{l}\text { After the road was } \\
\text { built }\end{array}$ & \\
\hline Ragi & 238.6 & 278.1 & +16.6 \\
\hline Combu & 558.2 & 693.1 & +24.2 \\
\hline Paddy & 7.84 .4 & 6871.1 & -3.1 \\
\hline Samai & 1031.2 & 1763.3 & $+35 . / 5$ \\
\hline Gram & 72.1 & 103.8 & +44.1 \\
\hline Gingelly & 195.6 & 279.1 & +42.7 \\
\hline Vegetables & 966.8 & 1170.3 & +21.0 \\
\hline Fruits & 78.7 & 76.0 & -3.4 \\
\hline Chillies & 1.1 .6 & 141.6 & +39.4 \\
\hline
\end{tabular}




\begin{tabular}{|l|r|r|c|}
\hline Tamarind & 16.9 & 16.0 & -5.3 \\
Tobacco & 4.9 & 21.4 & +336.7 \\
Cotton & 3.1 & 9.4 & +203.2 \\
Betel leaves & 17.4 & 19.1 & +19.8 \\
Eggs & 68.0 & 80.0 & +17.6 \\
Milk & 164.6 & 243.8 & +48.1 \\
\hline
\end{tabular}

Sugar mills are the backbone of the agrarian economy by providing a direct outlet for the sugarcane growers and the roads leading to this

\begin{tabular}{|l|c|c|c|c|c|}
\hline \multicolumn{1}{|c|}{ Type } & $\mathbf{1 9 5 1}$ & $\mathbf{1 9 5 6}$ & $\mathbf{1 9 6 1}$ & $\mathbf{1 9 6 6}^{\mathbf{1}}$ & $\mathbf{1 9 7 4}$ \\
\hline Bullock carts ('000 Numbers) & 669 & 640 & 665 & 628 & 595 \\
\hline Tractors & 224 & 822 & 1450 & 3728 & 7107 \\
\hline
\end{tabular}

There were 6,69,000 bullock carts in 1951 and the number has declined to 5,95,000 in 1974. This is ascribed to a rapid increase in the number of tractors. The number of tractors has increased from 224 to 7107 in 23 years. In turn, mechanisation of agriculture also require transport facilities to supply the farmer with fuel, lubricants and spare parts. Thus the impact of road is visible in the rapid increase of mechanised cultivation.

\section{Conclusion:}

To sum up, road development contributes to economic development in three main ways. Roadways enlarge the market and thereby further stimulates economic specialisation. Roadways help exploitations of additional resources by making them accessible. Roadways lead to establishment or expansion of related industries. Without efficient roads, investment in other spheres of development cannot produce the desired results. Even railways, air and water services need good roads to feed them. With increasing urbanization on the passenger traffic front, the Government is aggressively attempting to attract investment on the goods front, there is a significant pressure on the current roadways infrastructure in the country at both the National and State levels. However, there remain significant gaps and inefficiencies in road transportation, leading to higher time and monetary costs for road users in India as compared to other countries. It is estimated that transportation and logistics inefficiencies hinder GDP growth by approximately 2 percent.

\section{References:}

[1]. Infrastructure for Agriculture and Rural Development, An Impact Assessment of Investments in Rural Roads and Bridges under RIDF, National Bank for Agriculture and Rural Development, Mumbai, 2004, p. 53.

[2]. Report on Road Infrastructure and Efficiency of Use in Tamil Nadu, Confederation of Indian Industry, p. 14.

[3]. Narendra Singru, Asian Development Bank, 'Socioeconomic effects of Road Improvements', August 2007 , p. 37.

[4]. Rostow, W.W., The Stages of Economic Growth, Cambridge, 1960, p. 55.

[5]. Report on the Impact of Roads in Salem District, Highways and Rural Works Department, Madras, 1996 , p. 11.

[6]. Report of the Task Force on Transportation 1972-1984, p. 13.

[7]. Economic Benefits of the Ramnad-Mandapam Road 59-60, p. 12.

[8]. Tamil Nadu An Economic Appraisal 1972 - 1973, Madras, 1975, p. 35

[9]. Report of Chief Engineers on Road Development Plans for India 1961-81, Ministry of Transport and Communication, Department of Transport, Government of India, 1983, p. 101

[10]. Ashok V.Bhuleshkar, Towards Socialist Transformation of Indian Economy, Bombay, 1972, p. 265.

[11]. Arora, S.K., Economics of Management in Road Transport Industry, New Delhi, 1987, p. 26.

[12]. Administrative Report of Tamil Nadu State 2000 - 2001, Chennai, 2000, p. 271.

[13]. Policy Note 2007 - 2008, Highways Department, Chennai, 2007, p. 1.

[14]. Administrative Report of Tamil Nadu State 1994 - 95, Madras, 1994, p. 182.

[15]. Romila Chawla, Transport and Tourism, New Delhi, 2006, pp. 37 - 38.

[16]. Nanjundappa, D.M., Impact of Roads Development on Indian Economy, Bangalore, 1971, p. 266.

[17]. Romila Chawla, Transport and Tourism, New Delhi, 2006, pp. 37 - 38

[18]. Nanjundappa, D.M., Impact of Roads Development on Indian Economy, Bangalore, 1971, p. 266.

[19]. Venkataraman, N., "Mobility for Prosperity", Economic Times, $23^{\text {rd }}$ November 1977.

[20]. http://en.wikipedia.org/wiki/Indian_road_network.

[21]. http://en.wikipedia.org/wiki/Indian road network 